\title{
Gambaran Pasien dengan Benjolan Payudara yang Diperiksa Biopsi Aspirasi Jarum Halus di Yayasan Kanker Indonesia Tahun 2014-2018
}

\author{
Bellavya Pertiwi Samosir ${ }^{1}$, Rebecca $\mathbf{N}$ Angka ${ }^{2,3}$, Shintia Christina ${ }^{2}$, \\ Sutjahjo Endarjo ${ }^{3}$, Paramitha Pandansari ${ }^{3}$
}

\author{
${ }^{1}$ Fakultas Kedokteran dan Ilmu Kesehatan Universitas Kristen Krida Wacana, Jakarta, Indonesia \\ ${ }^{2}$ Departemen Histopatologi Anatomi, Fakultas Kedokteran dan Ilmu Kesehatan, Universitas Kristen Krida \\ Wacana, Jakarta, Indonesia \\ ${ }^{3}$ Klinik Utama Yayasan Kanker Indonesia \\ Alamat Korespondensi: bellavya.2016fk162@civitas.ukrida.ac.id
}

\begin{abstract}
Abstrak
Benjolan di payudara merupakan kondisi yang sering dialami oleh banyak perempuan. Benjolan ini disebabkan oleh tumbuhnya jaringan di dalam payudara yang dapat bersifat jinak atau ganas. Tujuan penelitian ini dilakukan untuk mengetahui gambaran benjolan payudara pada pasien yang melakukan Biopsi Aspirasi Jarum Halus (BAJAH) di Yayasan Kanker Indonesia tahun 2014-2018 berdasarkan jenis kelamin, usia, lokasi benjolan, mobilitas benjolan, batas benjolan, jumlah benjolan, dan juga hasil sitologi benjolan payudara. Sampel diperoleh dengan cara consecutive sampling. Data hasil pemeriksaan BAJAH dikumpulkan sesuai dengan kriteria inklusi. Pengolahan data menggunakan program statistik SPSS dan Microsoft excel. Total sampel sebanyak 536 sampel. Jenis kelamin perempuan sebanyak 531 pasien $(99,1 \%)$. Usia terbanyak adalah 40-49 tahun sebanyak 234 orang (43\%). Lokasi payudara kiri 252 orang (47\%). Benjolan mobile sebanyak 174 orang $(58,8 \%)$, batas benjolan tidak tegas sebanyak 249 orang $(60,6 \%)$. Jumlah benjolan soliter sebanyak 441 orang $(82,3 \%)$ dan benjolan multiple sebanyak 95 orang $(17,7 \%)$. Pasien dengan karsinoma mammae sebanyak 217 orang (40,5\%). Benjolan payudara lebih sering dialami perempuan.dibanding laki-laki. Pasien usia 40-49 tahun yang paling banyak didiagnosis karsinoma mammae, lokasi benjolan paling sering di sebelah kiri. Benjolan payudara immobile, soliter, dan berbatas tidak tegas paling banyak didiagnosis dengan karsinoma mammae.
\end{abstract}

Kata kunci: BAJAH, benjolan, payudara

\section{Description of Breast Lump Patients Performing Fine Needle Aspiration Biopsy at The Indonesia Cancer Foundation in 2014-2018}

\begin{abstract}
Numerous women often suffer from breast lump. Breast lump is caused by abnormally growing tissue inside the breast. There are two types of breast lump, benign or malignant. This study aims to describe breast lump patients who performed fine needle aspiration biopsy (FNAB) at the Main Clinic of the Indonesia Cancer Foundation in 2014-2018 based on gender, age, location of the lump, lump mobility, border of lumps, number of lumps, and also cytology results. The data of FNAB examination results were collected based on the inclusion criteria. The data was processed using statistical program SPSS and Microsoft Excel. The research had a total of 536 samples among which 531 (99.1\%) patients were female. The patients between 40-49 years old were 234 patients (43\%). Patients with a lump on the left breast were 252 (47\%). Patients with mobile lump were 174 (58.8\%), with unclear lump borders were 249 (60.6\%). Patients with solitary lump were 441 $(82.3 \%)$ and multiple lumps were 95 (17.7\%). Patients with carcinoma mamma were 217 (40.5\%). More women suffered from breast lumps than men. Most patients aged 40-49 years had carcinoma mamma with most lump positions on the left breast. Immobile, solitary, and unclear border of breast lumps were those of most diagnosed with carcinoma mamma.
\end{abstract}

Keywords : breast, FNAB, lump

How to Cite :

Samosir BP, Angka RN, Christina S, Endarjo S, Pandansari P. Gambaran Pasien dengan Benjolan Payudara yang Diperiksa Biopsi Aspirasi Jarum Halus di Yayasan Kanker Indonesia Tahun 2014-2018. J. Kdokt Meditek;27(1):9-15. Available from: http://ejournal.ukrida.ac.id/ojs/index.php/Meditek/article/view/1880. DOI: https://doi.org/10.36452/jkdoktmeditek.v27i1.1880 


\section{Pendahuluan}

Benjolan di payudara adalah kondisi yang sering dialami oleh banyak perempuan. Benjolan ini disebabkan oleh tumbuhnya jaringan dalam payudara yang dapat bersifat jinak atau ganas. Benjolan payudara yang paling sering dialami perempuan adalah kanker payudara. Kanker payudara merupakan masalah utama yang dihadapi saat ini. World Health Organization (WHO) melaporkan jumlah kasus kanker payudara menduduki peringkat kedua setelah kanker serviks yang paling banyak diderita oleh perempuan di dunia. Survei yang dilakukan WHO menyatakan 89 persen perempuan menderita kanker payudara. ${ }^{1}$ Insiden kanker payudara tertinggi terjadi di negaranegara maju. Namun saat ini juga kanker payudara terjadi di negara-negara yang memiliki insiden rendah. ${ }^{2}$ Berdasarkan data Global of cancer (GLOBOCAN) insiden kanker payudara sebesar 40 per 100.000 perempuan. Jumlah ini diperkirakan akan semakin meningkat seiring dengan perubahan pola hidup penduduk. ${ }^{2}$

Pentingnya melakukan deteksi dini pada benjolan di payudara adalah untuk mengetahui jenis benjolan yang diderita sehingga dapat melakukan penanganan yang tepat dan melakukan pencegahan dini agar tidak menjadi keganasan. Pemeriksaan yang digunakan untuk melakukan deteksi dini yaitu periksa payudara sendiri (SADARI). Setelah itu, untuk menegakkan diagnosis pasti maka

\section{Metodologi}

Penelitian ini bertujuan untuk mengetahui gambaran benjolan payudara pada pasien yang melakukan Biopsi Aspirasi Jarum Halus (BAJAH) di Yayasan Kanker Indonesia tahun 2014-2018, dengan pendekatan cross sectional. Populasi yang digunakan untuk penelitian ini adalah semua pasien dengan benjolan di payudara dan melakukan BAJAH di Klinik Utama Yayasan Kanker Indonesia, Lebak Bulus. Penelitian ini sudah mendapatkan surat keterangan lolos kaji etik nomor pengajuan: 735/SLKE$\mathrm{IM} / \mathrm{UKKW} / \mathrm{FK} / \mathrm{KE} / \mathrm{III} / 2019$.

Pengambilan sampel dilakukan dengan teknik consecutive sampling dari hasil formulir sitologi dan rekam medis pasien dengan benjolan di payudara di Klinik Utama Yayasan Kanker Indonesia selama tahun 2014-2018, sampel penelitian ini yaitu subjek yang melakukan BAJAH pada payudara sampai jumlah subjek minimal terpenuhi. Besar sampel minimal yang diperlukan adalah 157. Analisis data yang digunakan dalam penelitian ini adalah analisis dilakukan USG, mammografi, dan kemudian dilakukan Biopsi Aspirasi Jarum Halus (BAJAH). Teknik BAJAH aman, sederhana, tanpa komplikasi berat, murah, dan dapat dipercaya, dengan menggunakan jarum halus $25 \mathrm{G}$. Tindakan bedah dapat dikurangi sampai $50 \%$ kasus dengan pemeriksaan BAJAH. ${ }^{3}$

Sebuah studi mengemukakan sensitivitas BAJAH $90 \%$ dan spesifisitas $80 \%$. Peranan BAJAH sendiri di berbagai negara maju sudah sedemikian jauh dalam menentukan diagnosis suatu kelainan patologi dari jaringan tubuh, terutama dilakukan untuk menentukan tindakan lebih lanjut. ${ }^{3}$ Yayasan Kanker Indonesia adalah organisasi nirlaba yang bertujuan untuk membantu pemerintah dalam penanggulangan kanker. Yayasan Kanker Indonesia mempunyai 2 klinik deteksi dini. Salah satunya adalah Klinik Utama yang terletak di Lebak bulus, Jakarta Selatan. Sampai saat ini belum ada data demografi di Yayasan Kanker Indonesia mengenai benjolan di payudara yang dilakukan BAJAH. ${ }^{4}$

Penelitian ini bertujuan untuk mengetahui gambaran benjolan payudara pada pasien yang melakukan Biopsi Aspirasi Jarum Halus (BAJAH) di Yayasan Kanker Indonesia tahun 2014-2018 berdasarkan jenis kelamin, usia, lokasi benjolan, mobilitas benjolan, batas benjolan, jumlah benjolan, dan juga hasil sitologi benjolan payudara.

univariat meliputi jenis kelamin, usia, lokasi benjolan, mobilitas benjolan, batas benjolan, jumlah benjolan, dan juga hasil sitologi benjolan payudara.

\section{Hasil}

Penelitian ini dilakukan pada Juni 2019 sampai dengan Agustus 2019 di Klinik Utama Yayasan Kanker Indonesia. Sampel diambil dari formulir pemeriksaan sitologi pasien dengan benjolan di payudara yang telah dilakukan BAJAH di Klinik Utama Yayasan Kanker Indonesia dari tahun 20142018. Target sampel sebelum melakukan pengambilan data adalah 157 pasien. Setelah proses pengambilan data selesai, didapatkan sebanyak 536 sampel yang masuk kriteria inklusi, yaitu benjolan di payudara yang melakukan BAJAH. Dari 536 sampel yang masuk kriteria inklusi didapatkan diagnosis sitologi seperti karsinoma payudara, kista payudara, fibrokistik payudara, mastitis, dan abses payudara. 


\section{Jenis Kelamin}

Gejala yang timbul pada pasien dengan benjolan payudara beragam tergantung jenis benjolan. Benjolan pada payudara dapat bersifat jinak atau ganas. Benjolan pada payudara dapat terjadi pada perempuan dan juga pada laki-laki. ${ }^{5}$ Berdasarkan penelitian ini, jenis kelamin perempuan memiliki jumlah yang lebih banyak daripada laki-laki, dengan perempuan sebanyak 531 orang $(99,1 \%)$ dan laki-laki sebanyak 5 orang $(0,9 \%)$. Benjolan payudara yang paling ditakuti adalah keganasan. Menurut WHO, kanker payudara adalah yang banyak dialami oleh perempuan. Pada laki-laki kanker payudara terjadi $1 \%$ dari seluruh kasus. Pada 2018, kasus kanker payudara menyebabkan 627.000 kematian pada perempuan. ${ }^{1}$ Berdasarkan penelitian di Amerika pada tahun 2017-2018 terjadi peningkatan 252.710 kasus baru pada perempuan dan 2.470 kasus pada laki-laki. ${ }^{6}$

Pada penelitian yang dilakukan oleh Movahed et al (2019) didapatkan sebanyak 5.975 kasus kanker payudara $(97,2 \%)$ terjadi pada perempuan di Iran dan sebanyak 172 kasus kanker payudara $(2,8 \%)$ terjadi pada laki-laki di Iran. ${ }^{7}$ Penelitian ini sejalan dengan penelitian Movahed et al (2019), bahwa kasus terbanyak terjadi pada perempuan dibandingkan laki-laki. Hal ini berhubungan dengan faktor hormonal di mana perempuan memiliki hormon estrogen.

\section{Usia}

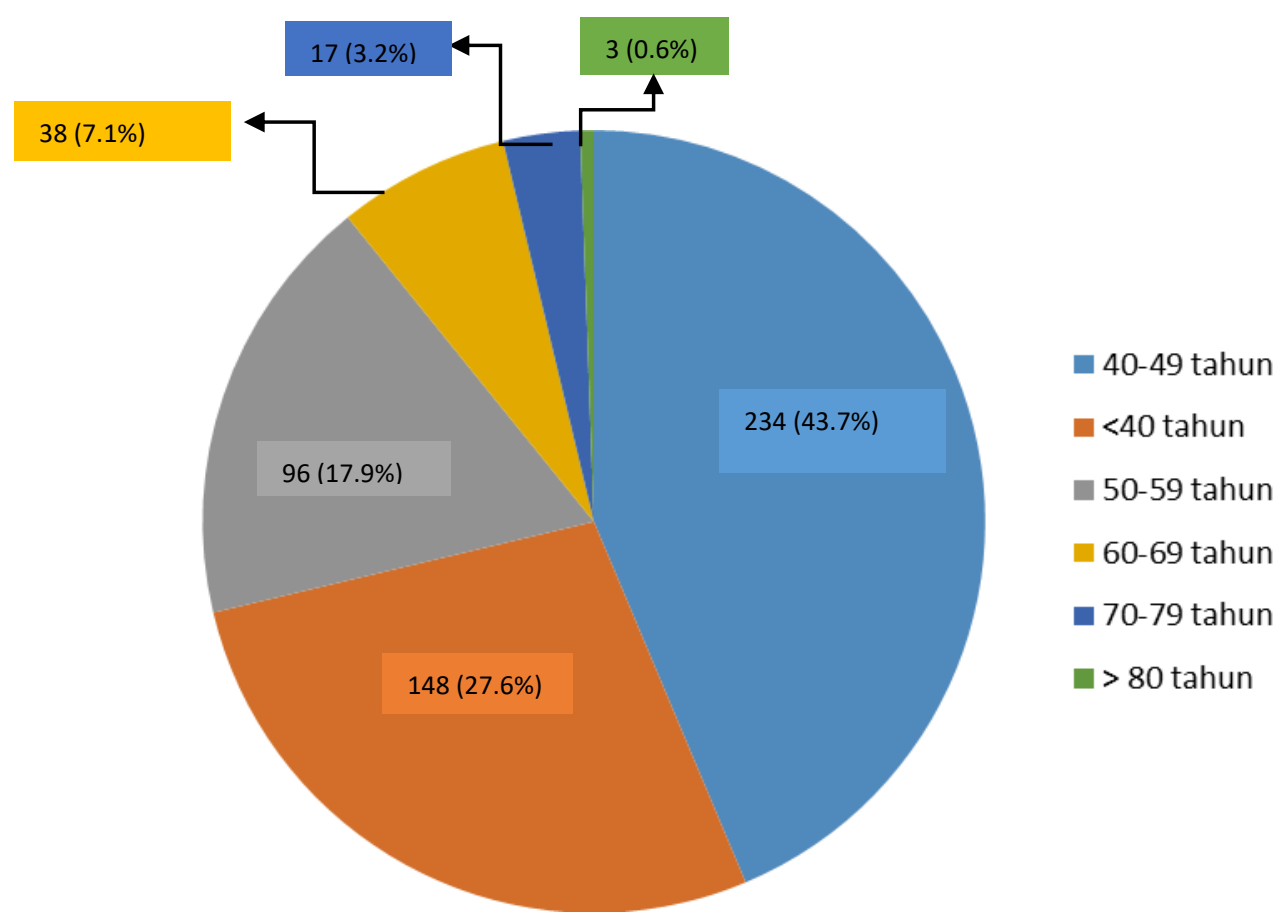

Gambar 1. Distribusi Berdasarkan Usia Pasien dengan Benjolan Payudara yang Melakukan BAJAH

Berdasarkan kelompok usia pada penelitian ini, usia terbanyak adalah usia 40-49 tahun yaitu sebanyak 234 orang (43\%) (Gambar 1). Pada penelitian ini pasien dengan usia 40-49 tahun banyak yang didiagnosis kanker payudara yaitu sebanyak 93 orang $(42,9 \%)$. Data di Amerika Serikat menunjukkan bahwa kelompok usia 60-69 tahun sebanyak 68.070 orang $(27 \%)$, kelompok usia 50-59 tahun sebanyak 58.620 orang (23\%). Sekitar 99,3\% dan 71,2\% kematian adalah usia antara 40 sampai 60 tahun di Amerika Serikat. ${ }^{6}$ Penelitian Nafissi et al (2018) di Iran menunjukkan bahwa kasus kanker payudara terbanyak berada di kelompok usia 45-49 tahun yaitu sebanyak $20,4 \%$. Dan sebanyak $18,6 \%$ pada kelompok usia 40-44 tahun. Hal ini menunjukkan bahwa kanker payudara di Iran banyak terjadi pada usia 40- 49 tahun. $^{8}$

Penelitian yang dilakukan oleh DeGennaro Jr et al (2018) didapatkan kelompok usia terbanyak adalah usia 40-49 tahun, yaitu sebanyak 144 orang $(28,4 \%)$, dan kelompok usia 50-59 tahun yaitu sebanyak 129 orang $(25,4 \%) .^{9}$ Penelitian ini sejalan dengan penelitian yang dilakukan DeGennaro Jr et al (2018). Didapatkan bahwa kelompok usia terbanyak adalah 40-49 tahun. Hal ini berkaitan dengan usia yang merupakan salah satu faktor risiko. 


\section{Lokasi}

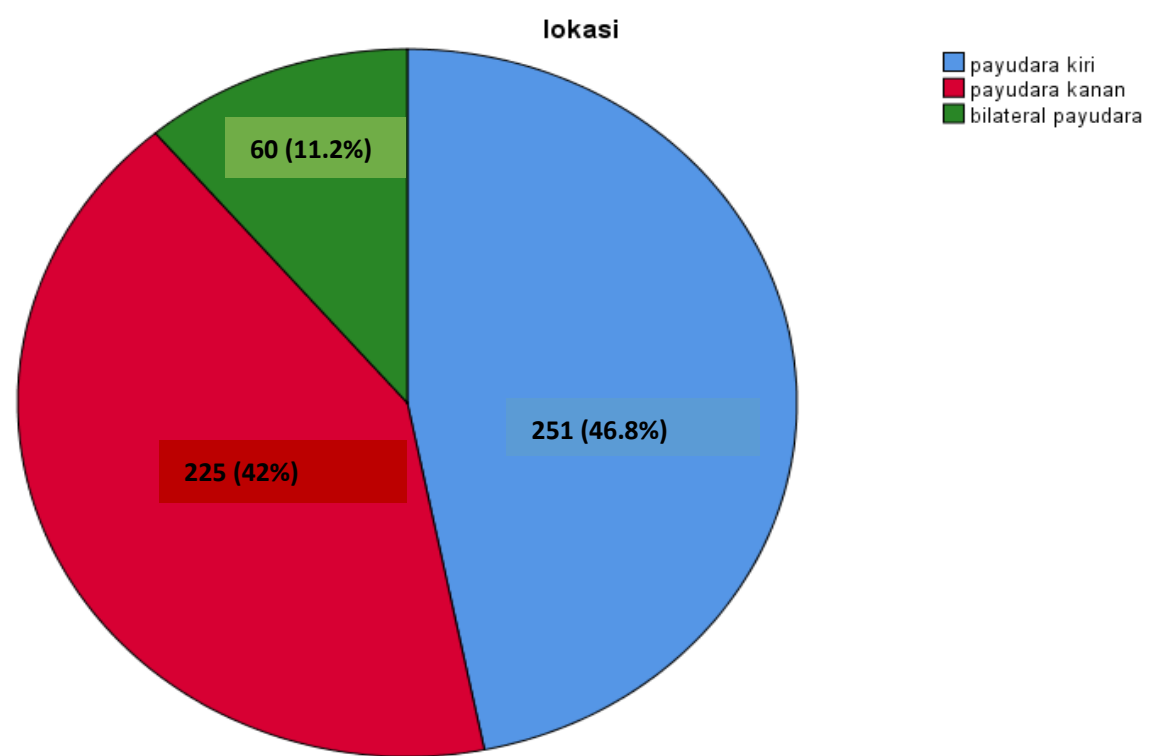

Gambar 2 Distribusi Berdasarkan Lokasi Pasien dengan Benjolan Payudara yang Melakukan BAJAH

Berdasarkan lokasi benjolan di payudara yang terbanyak adalah pada payudara kiri yaitu sebanyak 252 orang (47\%)(Gambar 2), dengan diagnosis keganasan sebanyak 217 orang $(40,5 \%)$ dan sebanyak 95 orang $(17,7 \%)$ dengan kista payudara. Penelitian yang dilakukan oleh Tareq et al (2019), lokasi benjolan payudara banyak ditemukan di sebelah kanan sebanyak 50,6\%, sebelah kiri ditemukan sebanyak (42,5\%), dan lokasi bilateral ditemukan sebanyak (6,9\%), dengan diagnosis benjolan terbanyak adalah fibroadenoma yaitu sebanyak 213 pasien $(35,8 \%)$ dan sebanyak 160 orang $(26,9 \%)$ carsinoma mammae. ${ }^{10}$ Penelitian yang dilakukan oleh Khan et al (2013), lokasi benjolan payudara terbanyak adalah pada payudara sebelah kiri, yaitu sebanyak 73 orang $(57,5 \%)$ dan 42 orang $(54,5 \%)$ pada payudara sebelah kanan, dengan diagnosis fibroadenoma sebanyak 59 orang $(46,5 \%)$ dan 44 pasien $(34,6 \%)$ dengan carsinoma mammae. ${ }^{11}$

Penelitian ini sejalan dengan penelitian yang dilakukan oleh Khan et al (2013), di mana lokasi benjolan terbanyak adalah di sebelah kiri. Tetapi lokasi benjolan pada payudara tidak menjadi suatu acuan untuk menentukan diagnosis benjolan pada payudara. Pemeriksaan penunjang sangat penting untuk menentukan diagnosis pasti benjolan di payudara

\section{Mobilitas}

Tabel 1. Distribusi Berdasarkan Mobilitas Pasien dengan Benjolan Payudara yang Melakukan BAJAH

\begin{tabular}{lclc}
\hline \multicolumn{2}{c}{ Imobile } & \multicolumn{2}{c}{ Mobile } \\
\hline Diagnosis & Jumlah & Diagnosis & Jumlah \\
Ganas & $90(73,8 \%)$ & Ganas & $46(26,4 \%)$ \\
Jinak & $32(26,2 \%)$ & Jinak & $128(73,6 \%)$ \\
Total & 112 & & 174 \\
\hline
\end{tabular}

Berdasarkan mobilitas atau pergerakan benjolan di payudara didapatkan sebanyak 296 pasien dari 536 pasien (Tabel 1). Menurut teori benjolan pada keganasan pada pemeriksaan payudara umumnya ditemukan immobile. Sedangkan benjolan jinak biasanya pada pemeriksaan fisik didapatkan benjolan yang mobile..$^{5}$ Penelitian yang dilakukan oleh Alema et al (2012) pada 85 pasien didapatkan bahwa dari 3 benjolan immobile 2 diantaranya dengan diagnosis keganasan (66,7\%). Dan dari 82 
benjolan mobile, didapakan 4 diantaranya dengan diagnosis keganasan $(4,9 \%) .^{12}$

Penelitian yang dilakuan oleh Ravi and Rodrigues (2012) pada 120 pasien didapatkan benjolan mobile sebanyak 99 pasien $(82,5 \%)$ benjolan immobile sebanyak 21 pasien (17.5\%). Benjolan immobile dengan keganasan didapatkan sebanyak 19 pasien dan jinak didapatkan 2 pasien. Sedangkan benjolan mobile dengan keganasan didapatkan sebanyak 36 orang, dan jinak didapatkan sebanyak 63 pasien. ${ }^{13}$
Penelitian ini sejalan dengan penelitian yang dilakukan oleh Ravi and Rodrigues (2012) yaitu didapatkan lebih banyak benjolan immobile dengan kegananasan. Benjolan dengan keganasan umumnya ditemukan immobile, tetapi pada beberapa kasus ditemukan benjolan mobile dengan keganasan.

\section{Batas Benjolan}

Tabel 2. Distribusi Berdasarkan Batas Benjolan Pasien dengan Benjolan Payudara yang Melakukan BAJAH

\begin{tabular}{cccc}
\hline \multicolumn{1}{c}{ Batas tidak tegas } & \multicolumn{2}{c}{ Batas tegas } \\
\hline Diagnosis & Jumlah & Diagnosis & Jumlah \\
Ganas & $138(55,4 \%)$ & Ganas & $45(27,8 \%)$ \\
Jinak & $111(44,6 \%)$ & Jinak & $117(72,2 \%)$ \\
Total & 249 & & 162 \\
\hline
\end{tabular}

Berdasarkan batas benjolan di payudara, didapatkan 411 orang dari 536 orang (lihat tabel 2). Berdasarkan teori, keganasan umumnya ditemukan pada benjolan dengan batas yang tidak tegas. Sedangkan benjolan jinak biasanya didapatkan benjolan yang berbatas tegas. ${ }^{10}$

Penelitian yang dilakukan oleh Alema et al (2012) pada 85 pasien didapatkan bahwa dari 6 pasien dengan benjolan berbatas tidak tegas, $4 \mathrm{di}$ antaranya dengan keganasan $(66,7 \%)$, dan dari 79 pasien dengan benjolan berbatas tegas, 2 diantaranya dengan keganasan $(2,5 \%) .{ }^{12}$ Penelitian yang dilakukan oleh Ravi and Rodrigues (2012) didapatkan bahwa benjolan dengan batas tegas sebanyak 87 pasien (72,5\%), dan benjolan dengan batas tidak tegas didapatkan 33 pasien $(27,5 \%)$. Benjolan batas tegas dengan keganasan didapatkan sebanyak 27 orang dan jinak sebanyak 60 orang. Benjolan berbatas tidak tegas dengan keganasan didapatkan sebanyak 28 orang dan jinak sebanyak 5 orang. ${ }^{13}$

Penelitian ini sejalan dengan penelitian yang dilakukan oleh Ravi and Rodrigues (2012) didapatkan lebih banyak benjolan batas tidak tegas dengan keganasan. Pada umumnya benjolan dengan keganasan ditemukan berbatas tidak tegas. Tetapi pada beberapa kasus ditemukan benjolan berbatas tegas dengan keganasan.
Berdasarkan data jumlah benjolan di payudara didapatkan sebanyak 441 orang $(82,3 \%)$ dengan benjolan soliter, dan sebanyak 95 orang $(17,7 \%)$ dengan benjolan multipel. Pada penelitian yang dilakukan oleh Surov et al (2012) didapatkan 19 orang $(53 \%)$ dengan benjolan multipel pada payudara dan 17 orang (47\%) dengan benjolan soliter pada payudara. ${ }^{14}$ Penelitian yang dilakukan oleh Chang et al (2011) pada 60 pasien didapatkan bahwa 53 pasien (88\%) dengan benjolan soliter pada payudara dan 7 pasien (12\%) dengan benjolan multipel pada payudara. ${ }^{15}$

Penelitian ini sejalan dengan penelitian yang dilakukan oleh Chang et al (2011). Pasien terbanyak adalah pasien dengan benjolan soliter di payudara. Penelitian ini juga didapatkan bahwa pada beberapa pasien dengan benjolan multipel didapatkan perbedaan hasil histopatologi pada benjolan di payudara. Sehingga banyaknya benjolan tidak menjadi suatu acuan untuk menentukan diagnosis benjolan pada payudara.

\section{Jumlah Benjolan}




\section{Hasil Sitologi}

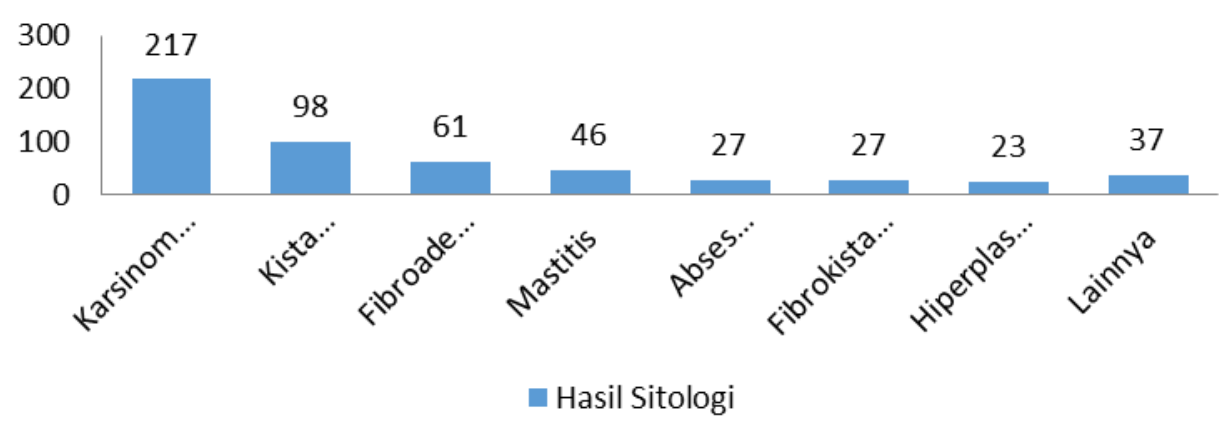

Gambar 3. Hasil Sitologi Pasien dengan Benjolan Payudara yang Melakukan BAJAH

Urutan 3 diagnosis sitologi terbanyak pada penelitian ini adalah carsinoma mammae yaitu pada 217 orang $(40,5 \%)$, kista payudara sebanyak 98 orang $(18,3 \%)$, dan fibroadenoma sebanyak 61 orang $(11,4 \%)$ (lihat gambar 3). Karsinoma didapatkan perempuan sebanyak 216 pasien $(99,5 \%)$ dan laki-laki sebanyak 1 pasien $(0,5 \%)$. Penelitian yang dilakukan oleh Ahmed et al (2010) didapatkan bahwa karsinoma payudara didapatkan sebanyak 68 kasus (34\%), 56 kasus (28\%) fibroadenoma dan 23 kasus $(11,5 \%)$ perubahan fibrokistik. $^{16}$

Penelitian yang dilakukan oleh Movahed et al (2019), menyatakan bahwa karsinoma payudara merupakan karsinoma yang sering terjadi pada perempuan. Di Amerika 12,4\% atau satu banding delapan perempuan terdiagnosis karsinoma payudara. Pada tahun 2012, terdapat 1,67 juta kasus baru pada seluruh dunia. ${ }^{7}$ Berdasarkan data WHO pada tahun 2018 diperkirakan 627.000 perempuan meninggal karena karsinoma payudara, dan mencapai $15 \%$ kematian yang disebabkan karsinoma pada perempuan. Hal ini menunjukkan bahwa karsinoma payudara adalah yang paling banyak terjadi pada perempuan. Penyebab pasti karsinoma payudara belum diketahui secara pasti. Namun ada beberapa faktor yang dikaitkan dengan kejadian karsinoma payudara seperti usia, faktor familial, faktor gen, faktor hormonal, faktor gaya hidup dan juga lingkungan. ${ }^{1}$

\section{Simpulan}

Berdasarkan penelitian yang dilakukan mengenai gambaran pasien dengan benjolan payudara yang diperiksa BAJAH di Yayasan Kanker Indonesia tahun 2014-2018, didapatkan hasil benjolan payudara paling sering dialami oleh perempuan di bandingkan laki-laki yaitu sebanyak 531 orang $(99,1 \%)$. Kelompok usia pasien dengan benjolan payudara terbanyak adalah 40-49 tahun yaitu sebanyak 234 orang (43\%). Berdasarkan lokasi benjolan, paling banyak di temukan pada payudara kiri yaitu sebanyak 252 orang (47\%). Berdasarkan mobilitas, benjolan immobile sebanyak 122 orang $(41,2 \%)$ dan benjolan mobile sebanyak 174 orang $(58,8 \%)$. Dari batas benjolan di payudara, didapatkan pasien dengan benjolan yang berbatas tidak tegas sebanyak 249 orang $(60,6 \%)$ dan berbatas tegas sebanyak 162 orang $(39,4 \%)$. Berdasarkan jumlah benjolan didapatkan sebanyak 441 orang $(82,3 \%)$ dengan benjolan soliter dan 95 orang $(17,7 \%)$ dengan benjolan multipel. Berdasarkan hasil pemeriksaan sitologi didapatkan diagnosis terbanyak adalah pasien dengan carsinoma mammae 217 orang (40,5\%), kista payudara 98 orang $(18,3 \%)$, fibroadenoma 61 orang $(11,4 \%)$.

\section{Daftar Pustaka}

1. WHO. Breast cancer. 2018. [cited 2019 Nov 10] Available from: https://www.who.int/cancer/prevention/diag nosis-screening/breast-cancer/en/.

2. Kementerian Kesehatan RI. Infodatin karsinoma payudara; Jakarta; 2016;2. [cited 2019 Nov 10] Available from: https://www.kemkes.go.id/article/view/1701 0500002/infodatin-kanker-payudara.html

3. Cahyaningtyas AY, Anggraini Y. Efektivitas health education "sadari" sebagai deteksi dini $\mathrm{Ca}$ mammae terhadap tingkat pengetahuan ibu PKK di Desa Triyagan. Jurnal Maternal. 2016;13(1):13.

4. Yayasan Kanker Indonesia. [cited 2018 Nov 26] Available from: http://yayasankankerindonesia.org/. $\quad 26$ november 2018. 
5. Virgilo C. Surgery a case based clinical review. Torrance, USA: Spinger; 2020: 43

6. American Cancer Society. Breast cancer fact and figures 2017-2018. [cited 2019 Des 2] Available from: https://www.cancer.org/content/dam/cancer -org/research/cancer-facts-andstatistics/breast-cancer-facts-andfigures/breast-cancer-facts-and-figures2017-2018.pdf

7. Momenimovahed Z, Salehiniya H. Epidemiological characteristics and risk factor for breast cancer in the world. Breast Cancer Dove Med Press. 2019;11:151-64.

8. Nafissi N, Khayamzadeh M, Zeinali Z, Pazooki D, Hosseini M, Akbari M. Epidemiologi and histopatologi of breast cancer in Iran versus other middle eastern countries. Middle East Journal of Cancer. 2018;9(3):243-51.

9. DeGennaro V, Jiwani F, Bernard J. Epidemiological, clinical, and histopathological features of breast cancer in Haiti. Journal of Global Oncology. 2018;4:19.

10. Tareq M, Goyani M S. Pattern of presentation of patients with breast cancer in Iraq in 2018, a cross-sectional study. Journal of Global Oncology. 2019;5:1-6.
11. Khan ZM, Jamal S, Khaliq T, Shabbir S. The frequency of various causes of breast lump in females presenting to surgical in tertiary care hospital. Pakistan Med.Sci. 2013;9(1):26-9.

12. Alema ON, Gakwaya AM. Comparision of fine needle aspiration cytology and fine needle sampling without aspiration in diagnosis of palpable breast lump in mulago hospital. East and Central African of Surgery. 2012;17(1):104-11.

13. Ravi C, Rodrigues G. Accuracy of clinical examination of breast lump in detecting malignancy: a retrospective study. Indian Journal of Surgical Oncology. 2012;3(2):154-7.

14. Surov A, Holzhausen H J, Wienke A, Schmidt J, Thomssen C, Arnold D, et al. Primary and secondary breast lymphoma: prevalence, clinical, signs, and radiological features. The British Journal of Radiology. 2012;85:195-205.

15. Chang JM, Han W, 6 nama?, et al. Papillary lesion initially diagnosed at ultrasoundguided vacuum- assisted breast biopsi: rate of malignancy based on subsequent surgical excision. Surgical Oncology. 2011;18:220614.

16. Ahmed HG, Ali AS. Frequency of breast cancer among sudanese patients with breast palpable lumps. Indian Journal of Cancer. 2010;47(1):23-6. 